九州大学学術情報リポジトリ

Kyushu University Institutional Repository

\title{
Study of Heat Pipe Utilizing Low-Temperature Geothermal Energy and Zeolite-A for Tea Leaves Withering Process
}

Gunawan, Yohanes

Heat Transfer Laboratory, Department of Mechanical Engineering University of Indonesia

Putra, Nandy

Heat Transfer Laboratory, Department of Mechanical Engineering University of Indonesia

Kusrini, Eny

Department of Chemical Engineering University of Indonesia

Imansyah Ibnu Hakim

Heat Transfer Laboratory, Department of Mechanical Engineering University of Indonesia

他

https://doi.org/10.5109/4055223

出版情報：Evergreen. 7 (2)，pp.221-227，2020-06. 九州大学グリーンテクノロジー研究教育センター バージョン：

権利関係 : 


\title{
Study of Heat Pipe Utilizing Low-Temperature Geothermal Energy and Zeolite-A for Tea Leaves Withering Process
}

\author{
Yohanes Gunawan ${ }^{1,3}$, Nandy Putra ${ }^{1, *}$, Eny Kusrini², Imansyah Ibnu Hakim , \\ Muhamad Dicky Hans Setiawan ${ }^{2}$ \\ ${ }^{1}$ Heat Transfer Laboratory, Department of Mechanical Engineering University of Indonesia, Campus UI, \\ Depok 16424, Indonesia \\ ${ }^{2}$ Department of Chemical Engineering University of Indonesia, Campus UI, Depok 16424, Indonesia \\ ${ }^{3}$ Research and Development Center for Electricity, New, Renewable Energy and Energy Conservation Technology \\ (P3tek KEBTKE), Ministry of Energy and Mineral Resources (KESDM) Republic Indonesia
}

*Corresponding Author’s email: nandyputra@eng.ui.ac.id

(Received October 10, 2019; Revised May 2, 2020; accepted May 21, 2020).

\begin{abstract}
Conventional drying methods can be improved by utilizing geothermal energy and the addition of Zeolite-A as an absorbent from the synthesis of Kaolin, which has abundant resources in Indonesia. The use of geothermal energy for fossil energy substitution results in the development of more sustainable and safer environmentally, while the use of Kaolin as absorbent will increase economic value and reduce the export of raw materials in Indonesia. This research was conducted to study the effect of adding Zeolite-A to the heat pipe heat exchanger (HPHE) system that utilizes geothermal energy to the performance of tea withering. As a source of geothermal fluid, a water heater with a capacity of 9000 Watts and hot water flowed with a pump were used. The HPHE used was constructed of 42 pcs of heat pipes and 181 pcs of the fin. The heat pipe used had a length of $700 \mathrm{~mm}$ with an outer diameter of $10 \mathrm{~mm}$, the fluid worked in the heat pipe using water with a filling ratio of $50 \%$.The fin was made of aluminum with a thickness of $0.105 \mathrm{~mm}$ with a size of $76 \times 345$ $\mathrm{mm}$. The results showed that the effectiveness of HPHE varied from $64.825 \%$ to $78.363 \%$. The Henderson and Pabis model was the best model to represent the behavior of tea leaves using Zeolite$\mathrm{A}$, and the Page model for the withering of tea leaves without Zeolite-A. With the addition of ZeoliteA, the speed of tea leaves withering increased by about $18 \%$. In addition to being environmentally friendly, the use of geothermal energy can be an alternative energy substitution for drying tea that uses firewood which is harmful to health because it becomes the source of anthraquinone (AQ) as a cause of cancer in humans.
\end{abstract}

Keywords: Heat Pipe, Low-Temperature Geothermal, Kaolin, Zeolite-A, Anthraquinone, Tea Leaves, Withering, Drying.

\section{Introduction}

The conventional drying methods have many disadvantages. The commodities which are dried by sundrying depend on the weather can only be done during the day and are easily contaminated by contaminants because they are dried in open courtyard. The method of drying tea leaves still uses fuel-wood and Industrial Diesel Oil (IDO) as a source of heat energy which has harmful effects on environmental and human health. Incomplete combustion of firewood produces polycyclic aromatic hydrocarbons (PAHs) which are a source of Anthraquinone (AQ) as a cause of cancer in humans ${ }^{1-3)}$. Thus, the use of solar energy, the use of fuel-wood and IDOs need to be combined with other energy or substituted with other more sustainable energy, one of which is geothermal energy which is also abundant in Indonesia.

The total geothermal energy potential is around 29,000 MW and is spread throughout Indonesia ${ }^{4}$. The constraint on direct use of geothermal energy is that flowing geothermal fluids must be with the help of a pump or flow due to differences in the height of the land so electricity must be available or differences in ground height. The use of pumps and production pipes is also susceptible to scaling and corrosion because geothermal fluids have high silica content and corrosion properties ${ }^{5-7}$. The use of a heat pipe to extract geothermal energy without flowing its fluid is one solution.

The heat pipe is a heat transfer device that has a high conductivity value. Applications of heat pipes are widely 
used for passive cooling in batteries, nuclear, electric motors or battery, rooms ${ }^{8-10}$. Kerrigan et al. designed heat pipe radiators to utilize low enthalpy geothermal energy, the result is that radiators that use heat pipes have many advantages compared to conventional radiator panels. The power density with a heat pipe is twice that of conventional radiator panels ${ }^{11)}$. The use of heat pipes for melting ice and snow applications utilizing heat from within the earth has also been carried out with satisfactory results ${ }^{12)}$.

The efficiency and quality of conventional drying also can be increased by the addition of zeolite as a desiccator, so that commodity drying can be carried out without high drying temperatures but using low humidity air, this makes the quality of commodities dried with the desiccator maintained ${ }^{13,14)}$. Djaeni et al. ${ }^{15)}$, in 2013, analysed the effects of drying conditions with several weight ratios of Zeolite and corn. Drying corn with Zeolite can speed up drying time and increase drying rate constants and corn nutrition can be maintained. In the following year, Djaeni et al. ${ }^{16)}$, conducted a study on the effect of drying conditions with several weight comparisons of Zeolite and seaweed, with additional variations in air humidity testing. With lower air humidity, energy for drying can be increased, without reducing the quality of seaweed. Utari et al. ${ }^{17)}$ also conducted a study on the use of rice with Zeolite. Zeolite drying can increase the drying rate by $19 \%$ compared to the dryer using only solar energy. The three studies above used a type of Zeolite 3A produced by Zeochem, Switzerland.

Indonesia, besides being rich in geothermal energy, is also rich in mineral resources, one of which is Kaolin. Data from the ministry of energy and mineral resources (KESDM) state that the production of Kaolin up to 2009 was around 32 million tons ${ }^{18)}$. To reduce the export of raw materials, it is necessary to downstream the minerals, as stipulated in Government Regulation (PP) No. 23 of 2010. One of the downstream efforts that can be done is to convert Kaolin into Zeolite-A through the synthesis process. After being converted to zeolite-A, Kaolin has a higher economic value. Based on research by Agustina et al. ${ }^{19)}$, the synthesis production of Kaolin to Zeolite-A has a value of feasibility in technical, economic, operational, and marketing.

This study was conducted to ensure that Kaolin from mines in Indonesia could be used as an absorbent in the dryer after being synthesized into Zeolite-A. The solution to the problem of $\mathrm{AQ}$ on tea leaves because of the conventional drying method using firewood and IDO was be given by substituting geothermal energy, so the plantation commodities chosen in this study were tea leaves. The effect of adding Zeolite-A to the speed of withering of tea leaves was be investigated. Heat pipe applications for direct use of geothermal energy as a solution to scaling problems and the absence of altitude differences for flowing geothermal fluids was also discussed.

\section{Methodology}

\subsection{Experimental Set Up}

Zeolite-A used in this study is a synthesis of Kaolin taken from mines in Bangka Belitung. The synthesis method used a method developed by Ayele et al. ${ }^{20)}$ with a little modification that eliminates the aging process ${ }^{21,22)}$.

Air heaters for drying in this experiment used the HPHE system, which functioned as a heat sink from the geothermal fluid that consisted of 42 pcs of heat pipes arranged staggered and 181 pcs of the fin. The material of heat pipe was copper, using wick in the form of sintered copper, the working fluid used was water with a filling ratio of $50 \%$. The dimensions of the heat pipe were $70 \mathrm{~cm}$ long, and the outer diameter was $1 \mathrm{~cm}$. The fin size was 76 x $345 \mathrm{~mm}$, made of aluminum with a thickness of 0.105 $\mathrm{mm}$. The dimensions of fin can be seen in Figure 1(c). The HPHE was divided into three areas, namely condensers, adiabatic, and evaporators with area lengths of $35 \mathrm{~cm}, 10$ $\mathrm{cm}$ and $25 \mathrm{~cm}$ respectively.

The geothermal liquid used in this experiment used a simulation with hot water from a water heater with a capacity of 9000 Watts and was flowed by a pump. The temperature of the water heater was regulated by temperature control, and the hot air flow was regulated by an inverter connected to the motor pump. Hot air flowed with the fan, and the flow could be adjusted through an inverter. The drying system with HPHE and all supporting equipment that has been installed can be seen in Figure 1(a).

The placement of sensors in this testing equipment is as seen in Figure 1(b). All thermocouples were connected to the NI-cDAQ 9214 module. All RH sensors were connected to the NI-cDAQ module. Sensors to measure the weight reduction of tea in the drying tray using a 1000gram Load Cell capacity connected to the NI-cDAQ 9237 module. The area of the Zeolite-A tray and drying tray were 360 x $360 \mathrm{~mm}^{2}$ respectively. A portable hot wire measured airflow in the ducting, and the hot water flow was measured using a flowmeter mounted after the water pump. The accuracy value of the all sensors in this experiment can be seen in Table 1.

Table 1. Accuracy of all sensors used

\begin{tabular}{|c|c|c|}
\hline No & Sensors & Accuracy \\
\hline 1 & Thermocouple & $\pm 5 \%{ }^{\circ} \mathrm{C}$ \\
\hline 2 & Relative humidity meter & $\pm 2 \%$ relative humidity \\
\hline 3 & Load Cell & $0.05 \%$ full scale \\
\hline 4 & Hotwire anemometer & $\begin{array}{c} \pm(5 \%+1 d) \text { reading or } \\
\pm(1 \%+1 d) \text { full scale } \\
\text { Depend on which is larger }\end{array}$ \\
\hline 5 & Water flow meter & $\pm 2 \%$ full scale \\
\hline
\end{tabular}




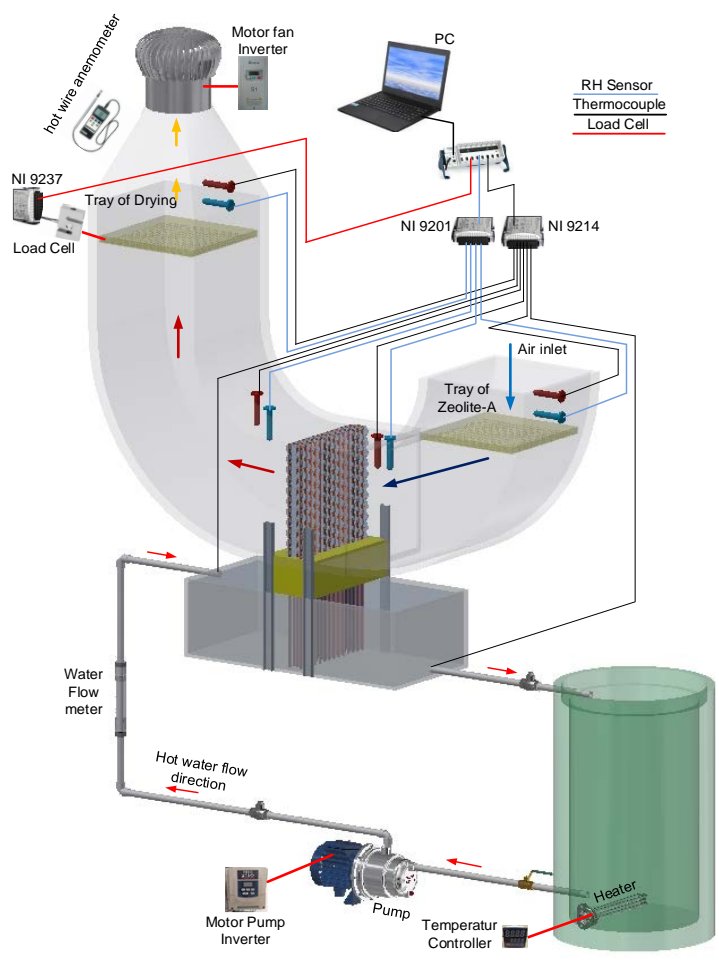

(a)

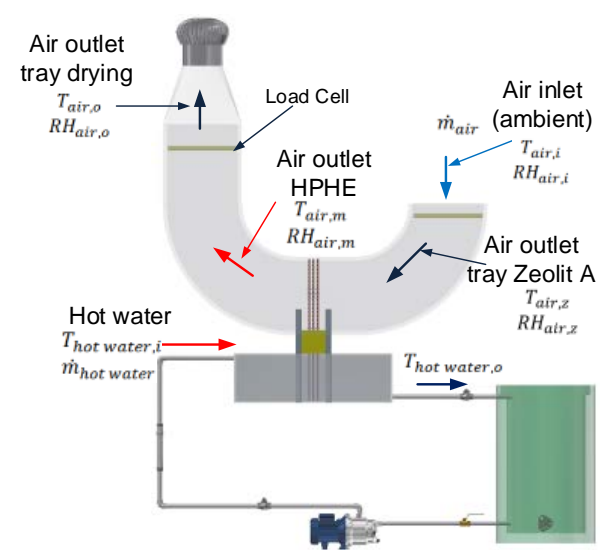

(b)

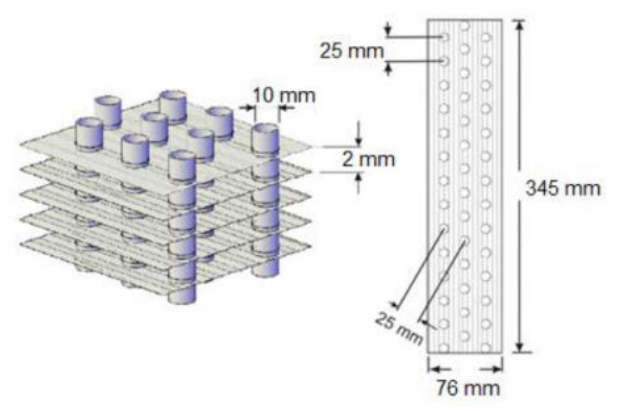

(c)

Fig. 1. (a) Schematic testing tool; (b) Schematic placement of measuring instruments; (c) Size of the fin

\subsection{Experimental Procedure}

To remove and evaporate water vapour and any water trapped in the pores of Zeolite-A before being used as an absorbent for the drying system at each change of variation test, Zeolite-A needed to be regenerated first. Regeneration was done by inserting Zeolite-A into the oven at $100{ }^{\circ} \mathrm{C}$ for 1 hour. Zeolite-A mass variations used were 100, 200, and 300 grams. After regeneration, Zeolite-A was left in the air vacuum container for 15 minutes so that the temperature dropped. Zeolite A was placed scattered over the tray, as seen in Figure 1(a).

The fresh tea leaves used in this study were picked from plantations in the Gunung Mas Tea Plantation area, PTPN VIII, located in Bogor, Indonesia. Before putting it in the drying tray, the tea leaves were measured initially in water content. Water content measurements were carried out by applying 1980 AOAC standards and ISO 712.

The measurement of tea leaves moisture content was carried out according to the following steps: Petri dish as a container for putting dried leaves in the oven at $105^{\circ} \mathrm{C}$ for 15 minutes. After that, to remove any residual moisture, the Petri Dish was put in the desiccator for 15 minutes, then weighed. Good tea leaves were selected and weighed \pm 3 grams. So, we got the weight of wet tea leaves. 3 grams of tea leaves were put into a Petri dish and put in an oven at $105^{\circ} \mathrm{C}$ for \pm 3 hours. Dry tea leaves were then put into the desiccator for 15 minutes, then weighed. The above process was repeated until the constant dry weight of tea was obtained (c $\leq 0.05$ ). So, we got the weight of dry tea. So, the moisture content of tea leaves was: Moisture content (dry basis) $=$ (weight of wet tea leaves - dry weight of tea leaves) / (dry weight of tea leaves) x $100 \%$. Water content (dry basis) = (weight of wet tea leaves - dry weight of tea leaves) / (weight of wet tea leaves) x $100 \%$.

Water heaters were set at a temperature of $50^{\circ} \mathrm{C}$. While the flow of hot water was set at a value of 18 liters/second, where this value was the optimal value of hot water flow in previous studies ${ }^{23)}$. Airspeed was chosen from Panchariya et al. ${ }^{24)}$ and was arranged as part of the independent variables, namely $0.2,0.4$, and $0.6 \mathrm{~m} / \mathrm{s}$.

The steady state was reached after about an hour the test equipment operated, and then the tea leaves were inserted into the drying tray and Zeolite-A into the Zeolite tray. For each variation, the test was carried out for two hours. The weight of 100 grams of tea was chosen because it adapted to the dimensions of the tray and according to the weight of tea in the same study ${ }^{24)}$. After the testing was complete, the weight of the tea and Zeolite-A was weighed with a digital scale to determine the final weight.

\subsection{Experiment Data and The Withering Model Validation}

The performance of HPHE could be indicated by the value of effectiveness $(\varepsilon)$, and was calculated by the following equation: 


$$
\varepsilon=\frac{T_{a i r, z}-T_{a i r, m}}{T_{\text {hotwater }, \text { in }}-T_{\text {air }, m}}
$$

The mathematical models for the process of withering and drying tea leaves used in this study were:

Henderson dan Pabis model:

$$
M R=\frac{M-M_{e}}{M_{o}-M_{e}}=A_{o} \exp \left(-k_{o} t\right)
$$

Page model:

$$
M R=\frac{M-M_{e}}{M_{o}-M_{e}}=\exp \left(-k_{o} t^{n}\right)
$$

Lewis model:

$$
M R=\frac{M-M_{e}}{M_{o}-M_{e}}=\exp \left(-k_{o} t\right)
$$

Page modified model:

$$
M R=\frac{M-M_{e}}{M_{o}-M_{e}}=\exp \left(-k_{o} t\right)^{n}
$$

In this analysis, the value of the equilibrium moisture content $\left(\mathrm{Me}_{\mathrm{e}}\right)$ was considered to have a value of 0 , because the relative humidity fluctuated, and the value was relatively small compared to $\mathrm{M}_{\mathrm{o}}$ and $\mathrm{M}$. The drying curve of tea leaves was matched to the experimental data using two different equations. $\chi$ ( $\chi$ square), $\mathrm{E}_{\mathrm{RMS}}$ (mean square error), $\mathrm{E}_{\mathrm{MB}}$ (mean square error), and $\mathrm{R}^{2}$ (R-Square) were used as the main criteria for selecting the best equation to account for variations in the drying curve of tea leaf samples and to determine the most suitable model. The lower the values above, the better the match.

\section{Result and Discussion}

\subsection{Temperature, Relative Humidity Profile, and the Effectiveness of HPHE}

The temperature profile of the hot water entering the HPHE, the hot water exiting the HPHE, the air entering the HPHE (ambient), the air exiting the Zeolite-A tray, the air out of the HPHE, and the air out of the drying tray in this test can be seen in Figure 2(a). Hot water inlet area evaporator of HPHE was maintained at $50{ }^{\circ} \mathrm{C}$. Airspeed was set at speeds of $0.2,0.4$, and $0.6 \mathrm{~m} / \mathrm{s}$. A steady state was achieved after the heater had been turned on for about 1 hour.

The temperature of hot water outside the evaporator area of the HPHE varied depending on the speed of the air flowing on the condenser side of the HPHE. At variations in air flow rates of $0.2,0.4,0.6 \mathrm{~m} / \mathrm{s}$, the temperature of hot water exiting HPHE was $49.7^{\circ} \mathrm{C}, 49.5^{\circ} \mathrm{C}$, and $49.2^{\circ} \mathrm{C}$, or the temperature difference was approximately $0.3,0.5,0.8$
${ }^{\circ} \mathrm{C}$, respectively. This indicates that the HPHE evaporator was successful in absorbing heat from incoming hot water, the amount of which depends on the amount of air velocity or the amount of heat released in the HPHE condenser area. The heat released in the area of the HPHE condenser was used to heat the inlet air that was used to wither tea leaves.

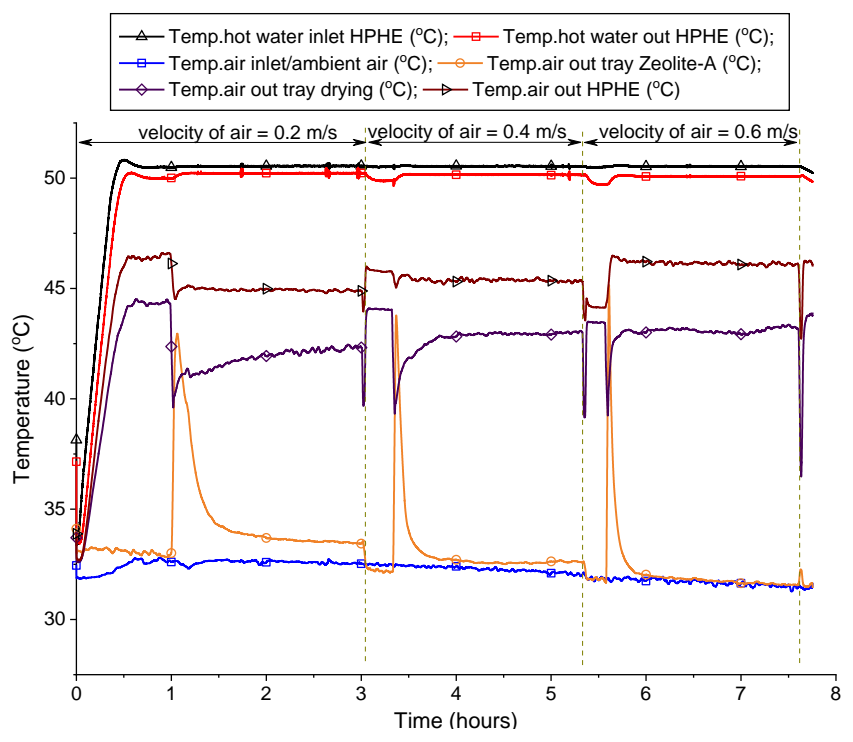

(a)

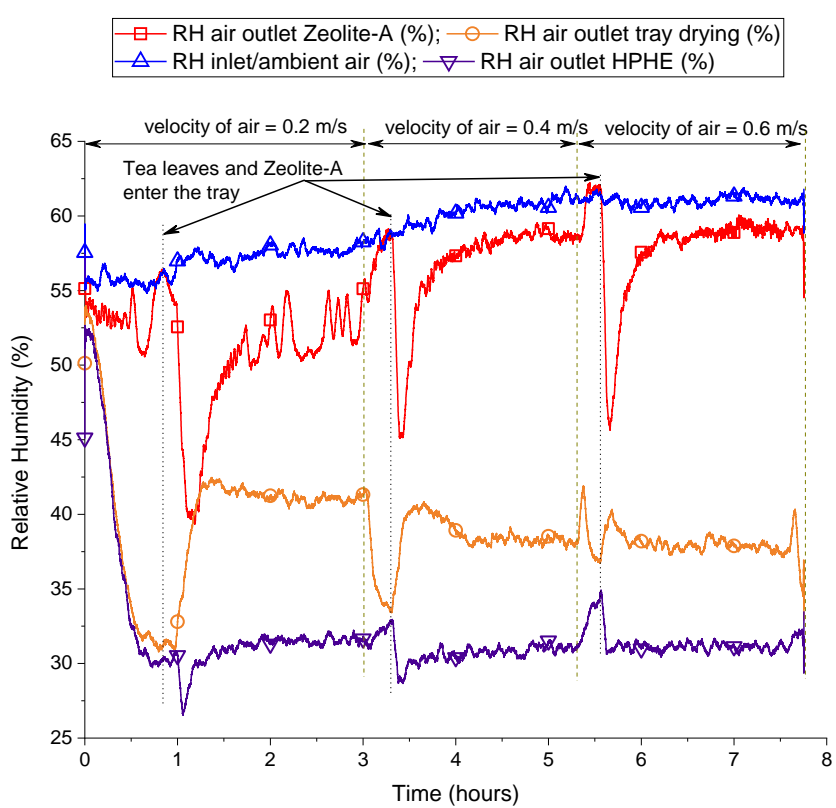

(b)

Fig. 2. (a) Temperature profile for variations of Zeolite-A 300-gram mass testing; (b) Profile of air humidity on variations of Zeolite-A 300 gram mass testing

Ambient air temperature was measured in the temperature range of $31-32{ }^{\circ} \mathrm{C}$. After Zeolite-A was inserted into the tray, the ambient air temperature passing through Zeolite-A immediately rose and then slowly dropped to near the ambient temperature again. The 
increase in air temperature when passing Zeolite-A occurred because of the influence of exothermic reactions from Zeolite-A with air. This was further confirmed by the decrease in the difference in air humidity between the humidity of the ambient air and the humidity of the air out of Zeolite-A, as shown in Figure 2(b). The humidity of the Zeolite-A air decreases and tends to rise near ambient air humidity along with time. The decrease in air humidity was caused by water vapor in the air passing through Zeolite-A to be absorbed. The phenomenon of rising air temperature and the decrease in air humidity passing through Zeolite-A indicate that Zeolite-A has worked as an absorber of moisture in the air.

The mass of water vapor absorbed was measured from the difference between Zeolite-A mass at the beginning and after completion of testing, as can be seen in Table 2 . The greater the mass of Zeolite-A used, the greater the ability to absorb moisture in the air. While the performance of the HPHE system in research with the addition of Zeolite-A can be seen from the value of its effectiveness, whose values ranged from 0.648 to 0.784 .

Table 2. Mass of water vapor in the air absorbed and effectiveness of HPHE

\begin{tabular}{|c|c|c|c|c|c|}
\hline No & $\begin{array}{c}\text { Initial } \\
\text { mass of } \\
\text { Zeolite-A } \\
\text { (gram) }\end{array}$ & $\begin{array}{c}\text { Velo } \\
\text { city } \\
\text { of } \\
\text { air } \\
\text { (m/s) }\end{array}$ & $\begin{array}{c}\text { Mass of } \\
\text { Zeolite-A } \\
\text { after two } \\
\text { hours as } \\
\text { absorber } \\
\text { (gram) }\end{array}$ & $\begin{array}{c}\text { Mass of } \\
\text { water } \\
\text { content in } \\
\text { the air } \\
\text { that was } \\
\text { absorbed } \\
\text { (gram) }\end{array}$ & $\begin{array}{c}\text { Effecti } \\
\text { veness } \\
\text { of } \\
\text { HPHE }\end{array}$ \\
\hline 1 & 100 & 0.2 & 104.464 & 4.464 & 0.703 \\
\hline 2 & 100 & 0.4 & 104.704 & 4.704 & 0.767 \\
\hline 3 & 100 & 0.6 & 105.078 & 5.078 & 0.784 \\
\hline 4 & 200 & 0.2 & 208.021 & 8.021 & 0.681 \\
\hline 5 & 200 & 0.4 & 207.524 & 7.524 & 0.711 \\
\hline 6 & 200 & 0.6 & 207.108 & 7.108 & 0.777 \\
\hline 7 & 300 & 0.2 & 311.777 & 11.777 & 0.648 \\
\hline 8 & 300 & 0.4 & 311.735 & 11.735 & 0.706 \\
\hline 9 & 300 & 0.6 & 311.683 & 11.683 & 0.762 \\
\hline
\end{tabular}

\subsection{The Withering Model}

The tea leaves in this test had moisture content around $77 \%$ of the wet base (w.b.). After being put into the drying tray, the weight of the tea leaves decreased. During drying, the heat from the hot water removed by HPHE was used to evaporate the water in the tea leaves through a process of conduction and convection onto the surface of the tea leaves. After the water had evaporated and migrated to the surface of the tea leaf, water vapor was exhaled into the air and taken outside the drying tray. This could be confirmed by increasing the humidity value at the air out of the drying tray air, as shown in Figure 2(b). For the process of withering the tea leaves, the expected target of tea leaf moisture was $56 \%$ (w.b. $)^{25)}$. The drying speed was also determined by the velocity of the air flow. From Figure 3(a), it can be seen that higher air flow rate provided higher drying speed at the same time than the previous drying time.

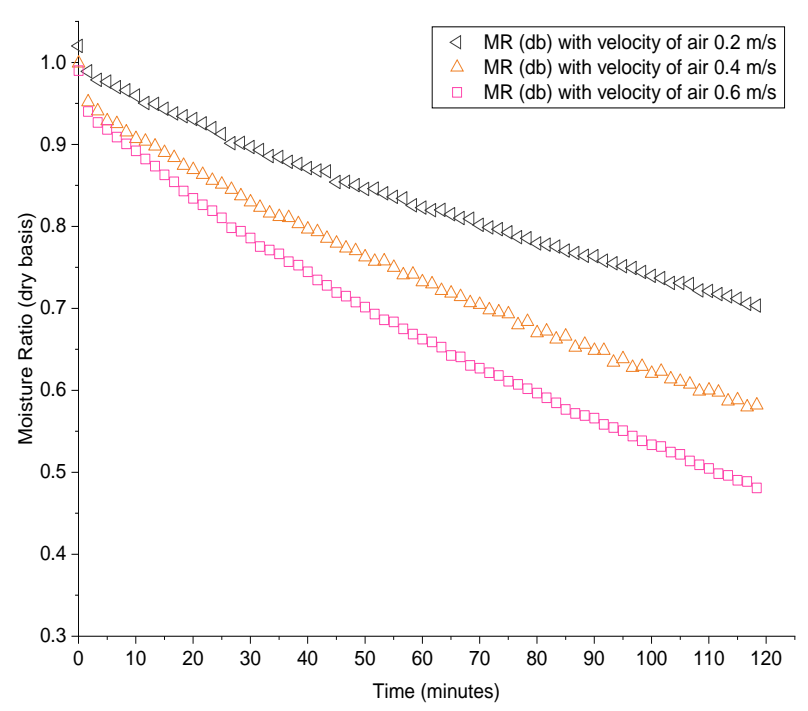

(a)

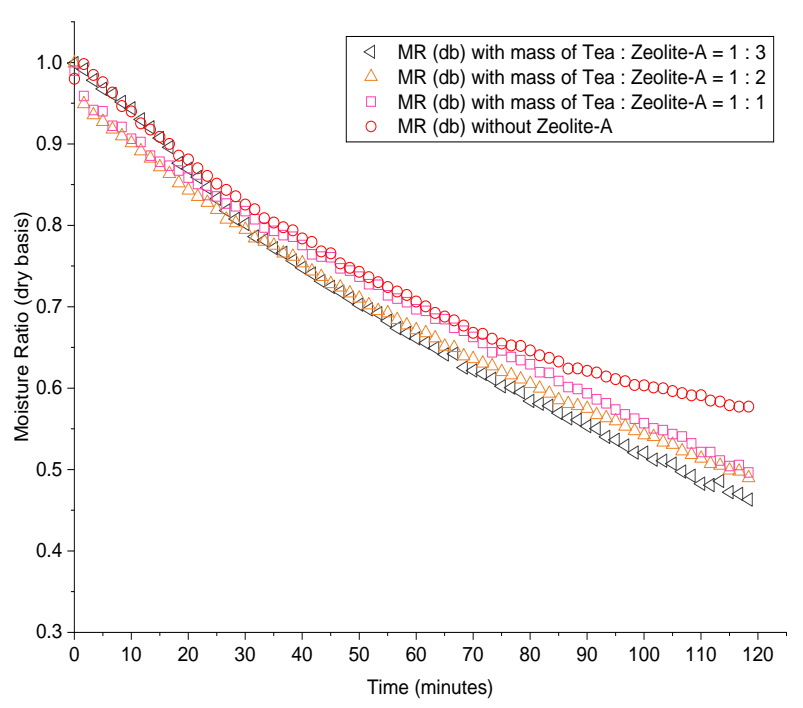

(b)

Fig. 3. (a) MR curve for 200 grams of Zeolite-A mass; (b) Comparison of MR at airspeed $0.6 \mathrm{~m} / \mathrm{s}$ with and without Zeolite-A.

The drying speed of tea leaves was also influenced by the addition of Zeolite-A mass. As shown in Figure 3(b), the drying speed on the MR graph shows that drying with the addition of Zeolite-A curves formed steeper than drying without using Zeolite-A. This shows that with the addition of Zeolite-A, it accelerated the time of tea leaves withering. The effect of the ratio of the mass of zeolite-A and tea leaves to drying time and moisture content can 
also be seen in Figure 3(b). With a higher mass of ZeoliteA ratio, it accelerated the time of drying. This happened because, with higher mass of Zeolite-A, the performance to absorb more water content in the air was higher, although a larger fan suction was needed so the air could penetrate the Zeolite-A mass into the tea leaf withering system. From Table 1, it can also be seen that with the mass of Zeolite-A being greater, the amount of water vapor absorbed was also getting bigger.

From the pattern of MR curve obtained, as shown in Figure 3(b), the MR curve was fit with the mathematical model in equation 2 to equation 5 . From the summary of the results of the analysis, it appeared that the Henderson and Pabis models consistently provided higher $\mathrm{R}^{2}$ for the MR reduction pattern on drying using Zeolite-A. Meanwhile, the Page model consistently provided higher $\mathrm{R}^{2}$ for the MR reduction pattern in drying without ZeoliteA. To get the water content of $56 \%$ (w.b.) as the final indicator of tea leaf removal, the time needed by the withering system with Zeolite-A with a ratio of 1: 1, 1: 2, 1: 3, and without Zeolite were 2154, 2060, 1946, and 2501 seconds, respectively. The time average with Zeolite-A for all the mass of Zeolite-A and tea leaves ratios was 2053 seconds, and when compared to without using Zeolite-A the difference was around $18 \%$. This result was similar to the experiment result conducted by Utari et $\mathrm{al}^{17)}$.

\section{Conclusion}

The HPHE system has successfully absorbed heat effectively from hot water to be transferred to the drying chamber without fluid withdrawal. System performance can be seen from the effectiveness of HPHE, whose values vary from $64.8 \%$ to $78.4 \%$. The Henderson and Pabis model is the best model to represent the behavior of tea leaves using Zeolite-A, and the Page model for the withering of tea leaves without Zeolite-A. The withering tea leaves using Zeolite-A can speed up the withering time by about $18 \%$ more than the withering without using Zeolite-A.

\section{Acknowledgements}

The author would like to thank the Directorate of Research and Community Engagements University of Indonesia (DRPM UI) for funding this research through the PITTA A SCHEME 2019.

\section{Nomenclature}

$T_{\text {air, }} \quad$ Temperature of air outlet tray of the Zeolite$\mathrm{A}\left({ }^{\circ} \mathrm{C}\right)$

$T_{\text {air,m }} \quad$ Temperature of air outlet HPHE in condenser area $\left({ }^{\circ} \mathrm{C}\right)$

$T_{\text {hot water, } i}$ Temperature of hot water inlet HPHE in evaporator area $\left({ }^{\circ} \mathrm{C}\right)$

M Moisture content of tea leaves \% (d.b.)

$M_{e} \quad$ Equilibrium moisture content \% (d.b.)

$M_{o} \quad$ Initial moisture content \% (d.b.)

$m \quad$ Wet mass of the cocoa beans (gram)

$m_{d} \quad$ Dry mass of the cocoa beans (gram)

$\mathrm{t}$ time (h)

$\mathrm{A}_{0} \quad$ model coefficient

$\mathrm{n} \quad$ exponent

$\mathrm{k}_{\mathrm{o}} \quad$ drying rate constant $\left(\mathrm{h}^{-1}\right)$

\section{References}

1) J. Pincemaille, C. Schummer, E. Heinen, and G. Moris, "Determination of polycyclic aromatic hydrocarbons in smoked and non-smoked black teas and tea infusions," Food Chem., (2014). doi:10.1016/j.foodchem.2013.08.121.

2) A. Adisa, A. Jimenez, C. Woodham, K. Anthony, T. Nguyen, and M.A. Saleh, "Determination of polycyclic aromatic hydrocarbons in dry tea," $J$. Environ. Sci. Heal. - Part B Pestic. Food Contam. Agric. Wastes, (2015). doi:10.1080/03601234.2015.1028832.

3) A.M. Abd El-Aty, J.H. Choi, M.M. Rahman, S.W. Kim, A. Tosun, and J.H. Shim, "Residues and contaminants in tea and tea infusions: a review," Food Addit. Contam. - Part A Chem. Anal. Control. Expo. Risk Assess., (2014). doi:10.1080/19440049.2014.958575.

4) A. Fauzi, "Revision of geothermal resource classification in indonesia based on type of potential power generation,” World Geotherm. Congr. 2015, (2015).

5) A. Franco, and M. Vaccaro, "On the use of heat pipe principle for the exploitation of medium-low temperature geothermal resources," Appl. Therm. Eng.,

(2013). doi:10.1016/j.applthermaleng.2013.05.024.

6) N.A. Pambudi, R. Itoi, S. Jalilinasrabady, and K. Jaelani, "Exergy analysis and optimization of dieng single-flash geothermal power plant," Energy Convers. Manag., (2014). doi:10.1016/j.enconman.2013.10.073.

7) N.A. Pambudi, R. Itoi, R. Yamashiro, B.Y. CSS Syah Alam, L. Tusara, S. Jalilinasrabady, and J. Khasani, "The behavior of silica in geothermal brine from dieng geothermal power plant, indonesia," Geothermics,

(2015). doi:10.1016/j.geothermics.2014.12.003.

8) M.H. Kusuma, N. Putra, A.R. Antariksawan, Susyadi, and F.A. Imawan, "Investigation of the thermal 
performance of a vertical two-phase closed thermosyphon as a passive cooling system for a nuclear reactor spent fuel storage pool,” Nucl. Eng. Technol., (2017). doi:10.1016/j.net.2016.10.008.

9) N. Putra, B. Ariantara, and R.A. Pamungkas, "Experimental investigation on performance of lithium-ion battery thermal management system using flat plate loop heat pipe for electric vehicle application,” in: Appl. Therm. Eng., 2016. doi:10.1016/j.applthermaleng.2016.01.123.

10) S. Muhammaddiyah, A. Winarta, and N. Putra, "Experimental study of multi-fin heat pipe heat exchanger for energy efficiency in operating room air systems," Int. J. Technol., (2018). doi:10.14716/ijtech.v9i2.1150.

11) K. Kerrigan, H. Jouhara, G.E. O’Donnell, and A.J. Robinson, "Heat pipe-based radiator for low grade geothermal energy conversion in domestic space heating," Simul. Model. Pract. Theory, (2011). doi:10.1016/j.simpat.2010.05.020.

12) R. Zorn, H. Steger, and T. Kölbel, "De-icing and snow melting system with innovative heat pipe technology," Proc. World Geotherm. Congr., (2015).

13) S. Hanif, M. Sultan, T. Miyazaki, and S. Koyama, "Steady-state investigation of desiccant drying system for agricultural applications," Evergreen, (2018).

14) I. Yaningsih, M.H. Mahmood, A.T. Wijayanta, T. Miyazaki, and S. Koyama, "Experimental study on dehumidification technology using honeycomb desiccant block,” Evergreen, (2018). doi:10.5109/1936212.

15) M. Djaeni, N.A. Aishah, H. Nissaulfasha, and L. Buchori, "Corn drying with zeolite in the fluidized bed dryer under medium temperature," IPTEK J. Technol. Sci.,

(2013). doi:10.12962/j20882033.v24i2.182.

16) M. Djaeni, and D.A. Sari, "Low temperature seaweed drying using dehumidified air," Procedia Environ. Sci., (2015). doi:10.1016/j.proenv.2015.01.002.

17) F.D. Utari, M. Djaeni, and F. Irfandy, “Constant rate of paddy rice drying using air dehumidification with zeolite,” in: IOP Conf. Ser. Earth Environ. Sci., 2018. doi:10.1088/1755-1315/102/1/012067.

18) K.E. dan S.D.M. Pusat Sumber Daya Geologi, Badan Geologi, "EXECUTIVE SUMMARY PEMUTAKHIRAN DATA DAN NERACA SUMBER DAYA MINERAL STATUS 2015,” 2015.

19) A.A.Y. Simanjuntak, and E. Kusrini, "Feasibility Study for Production of Zeolite A based on Kaolin," in: E3S Web Conf., 2018. doi:10.1051/e3sconf/20186702017.

20) L. Ayele, J. Pérez-Pariente, Y. Chebude, and I. Díaz, "Synthesis of zeolite a from ethiopian kaolin," Microporous Mesoporous Mater., (2015). doi:10.1016/j.micromeso.2015.05.022.

21) I. Petrov, and T. Michalev, "Synthesis of zeolite a: a review,” НАУЧНИ ТРУДОВЕ НА РУСЕНСКИЯ УНИВЕРСИТЕТ (Proceedings - Chem. Technol., (2012).

22) M. Gougazeh, and J.C. Buhl, "Synthesis and characterization of zeolite a by hydrothermal transformation of natural jordanian kaolin,” J. Assoc. Arab Univ. Basic Appl. Sci., (2014). doi:10.1016/j.jaubas.2013.03.007.

23) I.I. Hakim, N. Putra, and Y. Gunawan, "Experimental study for heat pipe applications on low enthalpy geothermal energy utilization for agricultural products dryers," J. Adv. Res. Fluid Mech. Therm. Sci., 56 (1) 68-77 (2019).

24) P.C. Panchariya, D. Popovic, and A.L. Sharma, “Thin-layer modelling of black tea drying process," $J$. Food Eng., (2002). doi:10.1016/S02608774(01)00126-1.

25) H.M. Ghodake, T.K. Goswami, and A. Chakraverty, "Mathematical modeling of withering characteristics of tea leaves," Dry. Technol., (2006). doi:10.1080/07373930600558979. 